\title{
Global migration and cities of the future
}

\author{
Barry Edmonston ${ }^{1}$ \\ Sharon Lee
}

\begin{abstract}
The number of lifetime international migrants worldwide has increased greatly in recent decades. Canada currently ranks as the fourth-largest immigrant-receiving country, with 8 million foreign-born residents in 2015. Most international migrants reside primarily in the large metropolises, with more than 60 per cent of Canada's foreign-born living in the Toronto, Vancouver, and Montreal urban conurbations. This paper examines four challenges of global migration for Canada's cities: housing and housing affordability, social services, employment, and integration and cohesion. The paper's conclusion discusses implications for expanding our knowledge base about global migration and cities of the future.
\end{abstract}

Keywords: international migration, immigration, immigration policy, immigrants and cities

\section{Résumé}

Le nombre de migrants internationaux à vie a considérablement augmenté au cours des dernières décennies. Le Canada se classe actuellement au quatrième rang des pays d'accueil des immigrants avec 8 millions de résidents nés à l'étranger en 2015. La plupart des migrants internationaux résident principalement dans de grandes métropoles, avec plus de 60 pourcent des personnes nées à Toronto, Vancouver et Montréal. agglomérations. Ce document examine quatre défis de la migration mondiale pour les villes canadiennes: l'abordabilité du logement et du logement, les services sociaux, l'emploi, l'intégration et la cohésion. La conclusion du document discute des implications pour élargir notre base de connaissance sur la migration globale et les villes du futur.

Mots-clés : migration internationale, immigration, politique d'immigration, immigrants et villes

\section{Recent trends in global migration}

The total number of lifetime international migrants worldwide grew from 175 million in 2000 to 222 million in 2010, and reached 244 million in 2015 (United Nations 2016). ${ }^{2}$ Currently, most international migrants reside primarily in the large metropolises of a dozen immigrant-receiving countries. The largest immigrant-receiving countries in 2015 were the United States (47 million foreign-born), Germany (12 million), United Kingdom ( 9 million), Canada (8 million), France (8

1. Barry Edmonston, corresponding author: Department of Sociology and Population Research Group, Box 3050 Stn CSC, University of Victoria, Victoria, BC V8W 3P5, email: be@uvic.ca; and Sharon M. Lee: Department of Sociology and Population Research Group, University of Victoria.

2. United Nations data on the stock of lifetime international migrants is an estimate of the number of people living in a country other than the country of their birth. Lifetime international migration data are estimated by the United Nations from national population censuses, population registers, or representative sample surveys. Data on the foreign-born depend on national statistical definitions: most countries include legal permanent immigrants, naturalized citizens, and refugees but usually exclude some persons, such as foreign diplomats, from national counts. Countries vary in whether the national data include illegal immigrants, temporary foreign-born workers, or foreign students. United Nations data on annual net immigration flows are derived from changes in the stock of lifetime international migrants. 
million), and Australia (7 million). In 2015, most of the lifetime immigrants worldwide (43 per cent) originated from Asia (United Nations 2016: 15). Europe comprised the second-largest number $(25$ per cent), with fewer immigrants worldwide originating from Latin America (15 per cent) or Africa (14 per cent).

During the recent 2007-15 period, the United States received the largest number of permanent immigrants, averaging slightly more than one million annually (see Figure 1, which shows data for selected countries in the OECD, which is a membership group of 32 democratic developed nations). Four populous European countries-Germany, United Kingdom, Italy, and Spain-received between 300,000 to 400,000 immigrants each year. Canada received 260,000 annually, with France receiving 230,000 and Australia receiving 220,000 during the same nine-year period. Two other European countries that are not shown in Figure 1 - Switzerland and the Netherlands - also received more than 100,000 immigrants each year, on average.

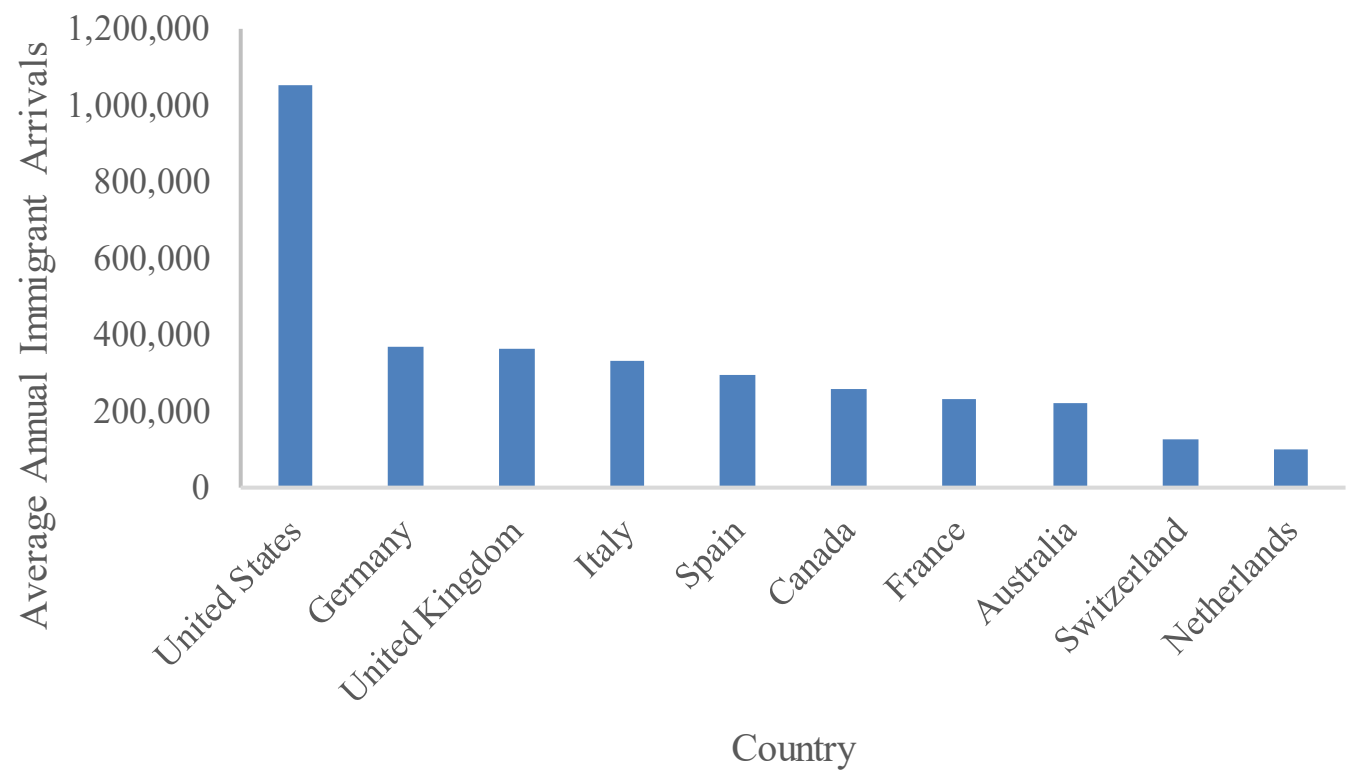

Figure 1. Average annual number of permanent immigrant arrivals for top eight immigrantreceiving OECD Countries, 2007 to 2015.

Source: Number of arrivals are from OECD 2017.

The ten countries displayed in Figure 1 vary greatly in population size. Figure 2 takes population size into account by showing the number of annual immigrant arrivals per 1 million resident population for five selected OECD countries. Australia and Canada both have had relatively high rates of immigrant arrivals per resident population, and their annual trends are fairly steady for 2007-15. Australia has been receiving about 10,000 annual immigrants per 1 million residents, while Canada has been receiving 7,500 per 1 million residents. Germany had increasing immigration rates during this period, with larger numbers of arrivals associated with recent large-scale refugee flows. Italy witnessed higher arrival rates in the early period when there were immigrant arrivals from within the European region (Spain is not shown but had trends similar to Italy). The United States had relatively lower rates of immigrant arrivals-about 3,400 annual immigrants per 1 million residents - that were fairly steady during this period (France and United Kingdom are not shown but had trends similar to the United States). 


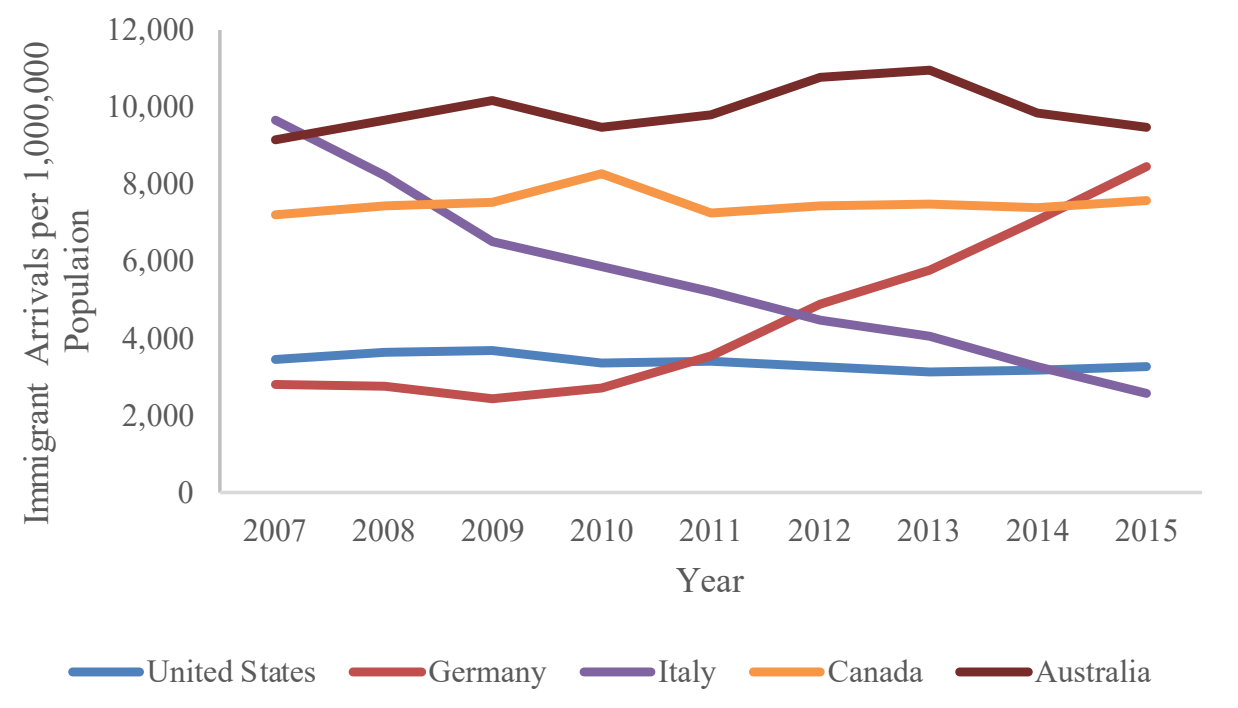

Figure 2. Annual number of permanent immigrant arrivals per 1 million resident population for five selected immigrant-receiving OECD countries, 2007 to 2015.

Source: Number of arrivals are from OECD 2017; population size figures are from Population Reference Bureau 2007 and 2015.

Both in Canada and worldwide, most immigrants originate from middle-income countries (United Nations 2016: 14). In the past fifteen years, immigrants originating from middle-income countries increased more rapidly than those from countries in either high- or low-income groups. Relatively few immigrants (less than 10 per cent worldwide) come from low-income countries.

\section{Recent immigration policy debates}

Immigration policy debates became prominent in recent decades because of high and persistent unemployment in many industrialized countries (OECD 2013). After the financial crises of 2007-08, labour markets in OECD countries recovered slowly, and large groups of the labour force experienced extended periods of unemployment. The sizable increases in immigrant flows to Europe and some other OECD countries in 2015-16 made the employment effects of immigrants a critical topic in public debate.

Recent research on the labour market outcomes of immigrants in the OECD provides two key findings (OECD 2017: 62). First, the unemployment rates of the foreign-born increased by 1.8 percentage points on average from 2015 to 2016 in all OECD countries combined, and by 4.3 percentage points in European countries. However, secondly, foreign-born residents in Canada and the United States recovered well from the financial crisis of the previous decade. Unemployment rates among the foreign-born in Canada and the United States decreased by 1.8 and 4.1 percentage points, respectively, between 2011 and 2016 (unemployment rates for Canada-born or US-born residents decreased by 0.6 and 3.4 percentage points, respectively, in Canada and the United States). Employment rates among older foreign-born residents had an especially strong recovery in Canada and the United States, growing by 5.4 and 3.6 percentage points, respectively.

More recently, immigration policy debate has centered on the refugee humanitarian crisis in Europe because of unprecedented large refugee inflows in 2015 and 2016. In 2017, however, the number of refugee arrivals in Europe dropped dramatically, to levels previously recorded in 2014 (OECD 2017). As a result, European immigration issues have shifted to concerns for helping refugees settle in their new host countries_-assuming that they are likely to stay for some time- 
and integrate into the destination countries' labour markets. Consequently, European immigration policy debates have moved from Europe-specific concerns with acute large refugee flows to broader concerns of immigrant integration faced by other immigrant-receiving countries outside of Europe. For further reading, the International Organization for Migration's (2017) World Migration Report 2018 discusses current global immigration policy issues, international migration trends, factors affecting migration, and the consequences of migration for countries of origin and destination.

While Canada's employment and fiscal situation is not as dire as that of some other countries, suggesting brighter prospects for the socio-economic integration of immigrants, Canada does resemble other immigrant-receiving countries (particularly Europe) in having an ageing population and workforce. Moreover, Canadian residents share similar concerns about immigration with the Europeans, where public opinion surveys reveal that about 50 per cent of those surveyed believe that immigrants contribute less in taxes than they receive in health, welfare, and other social services (Edmonston 2016: 27-28; OECD 2013). This belief underlies the public opinion that immigrants are a large burden on the public purse, with other residents paying higher taxes in order to support immigrants.

Studies in Canada, Europe, and the United States, however, conclude that the fiscal effect of immigration on the public purse is generally negligible, and is only negative where there is a large share of older foreign-born residents receiving public pensions (Blau and Mackie 2017: Chapter 8; OECD 2013). Skilled younger immigrants, on the other hand, are fiscal contributors to the public purse. Overall, according to a review published by OECD (2013:145), "some general tendencies from the literature seem to hold across most OECD countries. The fiscal effect [of immigration] is generally small...the impact generally fluctuates around $\pm 1 \%$ of GDP in most studies that look at the fiscal impact on the resident population in any given year." 3

The most recent United Nations' International Migration Report (2016) provides a context for understanding Canada's future international migration trends. Comparing annual immigration rates for three of the largest immigrant destinations (Australia, Canada, and the United States), Australia had slightly higher rates from 2000 to 2015; Canada experienced an increased rate from 2000 to 2010, followed by slight decreases to 2015, and the United States had steady rates from 2000 to 2010, followed by slight decreases to 2015. During the 2010-15 period, Canada had a net immigration rate of 7.6 per 1,000, which was one-third lower than that of Australia $(9.6$ per 1,000) and more than twice that of the United States (3.5 per 1,000). In 2015, immigrants comprised 28 per cent of the population of Australia and 22 per cent of Canada, while the comparable figure was 14 per cent for the United States.

Based on these past trends, we expect immigration to continue to be a major driver of future population growth and change in Canada. In addition, the total number of immigrants admitted each year may increase or decrease, depending on federal immigration policies that govern regular immigration and special categories of immigrants such as refugees.

\section{Emerging issues}

There is a close relationship between international migration to Canada and this country's cities. Historically, immigrants have been drawn to cities for work and because of immigrant social networks. These trends continue today. More than one-half (61 per cent) of all foreign-born in Canada live in the large Toronto, Vancouver, and Montreal urban conurbations (Statistics Canada

3. Because the proportion of national GDP spent on government services varies by country, comparisons of the net fiscal effect of immigrants usually present estimates of net fiscal effects as a per cent of overall GDP rather than a per cent of government spending. 
2017). Although some immigrants subsequently disperse from the big three to other urban areas, these metropolises dominate Canada's immigration scene. As the potential size, origin country, and ethnocultural diversity of immigrants continue to shift in future years, how will this influence Canada's metropolises and other urban areas? What are the implications and challenges for housing, social services, and employment, and for the social and economic inclusion and integration of immigrants and their descendants?

Three key elements provide a background for emerging issues related to immigration and cities. First, as previously noted, immigrants in Canada are overwhelmingly urban residents. Statistics Canada (2010: 26-27) reports that 81 per cent of the foreign-born resided in metropolitan areas in 2006, and in 203183 per cent are projected to live in metropolitan areas. Although the urban nature of immigrants in Canada is similar to other immigrant-destination countries, Canada's immigrants are moreover largely concentrated in only three metropolitan areas, while in other immigrant-receiving countries such as the United States, immigrants are dispersed in over a dozen metropolitan areas. A second background element is that metropolitan areas have little control over national immigration policies or over internal migration flows, but metropolitan areas must deal with the end results of migration. Third, metropolitan areas are increasingly the engines of economic growth in Canada.

Canada's top 9 metropolitan areas take up just 1 per cent of the nation's landmass. However, these areas are home to 57 per cent of the country's population, which generates the same proportion - 57 per cent_ of the national GDP (Florida et al. 2009). The three major metropolitan areas of Toronto, Montreal, and Vancouver alone account for more than one-third of the national economy. Thus, the national economy is becoming increasingly a network of metropolitan economies. These metropolitan areas and cities power the country's economic engine. They can also serve as an indicator of future development for the rest of the country. New demographic trends, particularly those related to growing immigrant populations, which are also more ethno-culturally diverse, are likely to happen at a faster pace in these areas.

The abovementioned background points suggest four key emerging issues for our consideration:

1. Canada is just one of five major countries that have continuously welcomed international migrants and permanent residents for the past fifty years (Australia, Israel, New Zealand, and the United States are the other four), and collectively accept about 1.7 million immigrants annually (OECD 2017). Meanwhile, the six largest sources for emigrants (excluding those who are temporary workers in other countries), according to 2015 data (United Nations 2016:1), are India (16 million), Mexico (12 million), Russia (11 million), China (10 million), Bangladesh (7 million), Pakistan (6 million), and Ukraine (6 million). But several major sources of international migrants, such as China and India, are also undergoing rapid development, raising questions about their future as sources of emigrants. Economic development, improvements in income, employment, and standard of living (together with increased political stability and other changes), and slower population growth resulting from lower fertility have led countries — such as Italy in previous decades and, more recently, South Korea - to transition from net emigration to net immigration countries. A key question is whether large rapidly developing countries such as China and India will make a similar transition, because such a transition would have major implications for Canada's sources of immigration. If immigration from China and India to Canada should slow down, it is possible that future immigration to Canada will include larger numbers from Africa and the Middle East, which will further expand Canada's ethno-cultural diversity. Therefore, while immigration will continue to be a major source of future population growth in Canada, we expect further increases in the diversity that immigrants bring to Canadian society. 
2. Although the majority of immigrants settle in Canada's largest metropolitan areas, our current understanding of migration in urban areas is inadequate. Censuses, surveys, and administrative data have not been adequately used to improve our understanding of the composition of immigrants and their adaptation and integration, and their effects on local labour markets and social services. This is an area that merits more research, which can help guide policymakers at both local and national levels.

3. Devolution has moved responsibilities and funding to local levels at the same time that globalization has increased international ties and the movement of products, services, people, and financing. In most cases, however, the shift in responsibilities to local areas has not been matched by an increase in resources from the federal government. Thus, financial challenges are likely to become more pressing in Canada's cities.

4. Immigration is increasing the ethnic diversity of Canadian cities, including diversity of ethnic origin, language, and religion. Because Canada's metropolitan areas have received most of the new immigrant arrivals, the foreign-born population is becoming concentrated in metropolitan areas and will increase the ethnic diversity of metropolitan areas in coming decades (Statistics Canada 2010; see Figure 3), with Toronto and Vancouverand, to a lesser extent, Montreal—becoming even more diverse by 2031 .

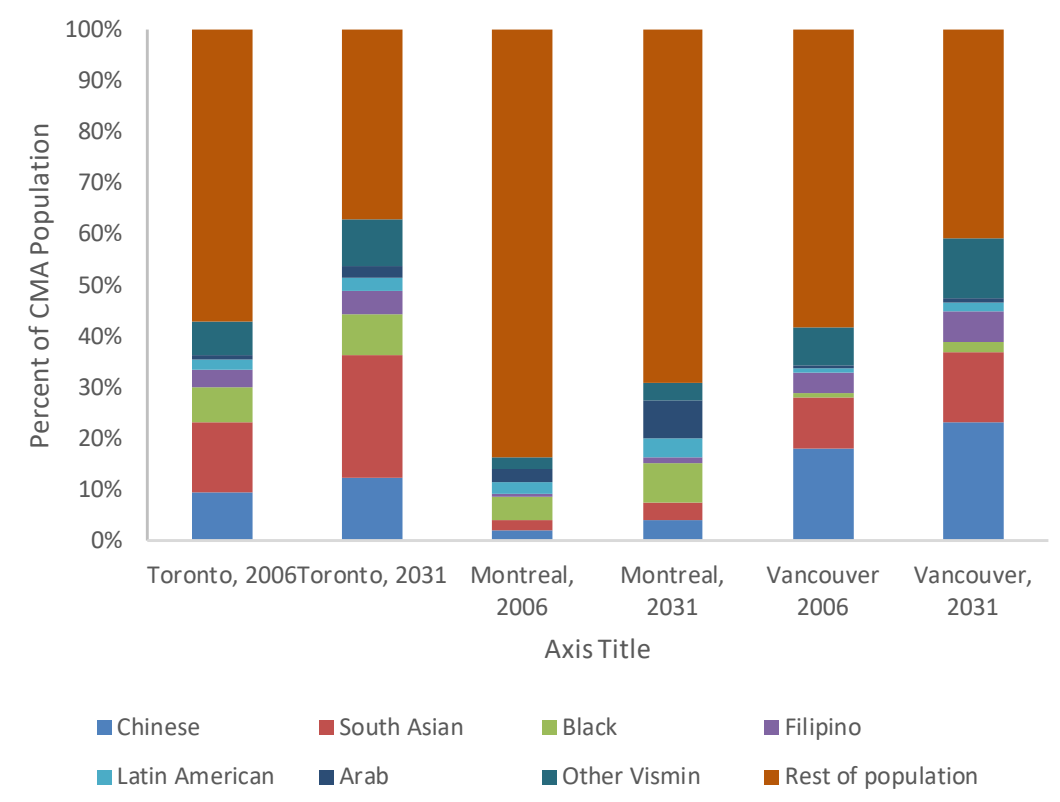

Figure 3. Distribution of Census Metropolitan Area population (CMA) by ethnic origin, Toronto, Montreal, and Vancouver, 2006 and 2031 (\%).

Source Statistics Canada 2010: Table A1.

\section{Immigration and challenges for Canadian cities}

Global migration presents four challenges for Canada's cities: (1) housing and housing affordability; (2) social services; (3) employment; and (4) integration and cohesion.

\section{Housing and housing affordability}

Housing is usually the first concern for new arrivals. Even if immigrants have employment, immigrants may experience difficulties understanding and accessing local housing markets. With 
the possible exception of immigrants who are being transferred by a large corporation, immigrants seldom have the background for accessing Canadian financial institutions, which makes immediate homeownership difficult. Most immigrants are likely to rent first, but landlords may look upon immigrants as unreliable tenants and may hesitate to rent to those without a previous rental record.

Immigrants in the past could more easily afford to purchase homes in central neighbourhoods of Canada's metropolitan areas, but this no longer appears possible on a large scale. Housing prices have continued to rise in Canada as well as other immigrant-receiving countries, such as Australia and New Zealand. Figure 4 shows housing price indices for Australia, Canada, and the United States for 2000 to 2016 as gauged by annual housing prices relative to household income. Housing prices may become unsustainable if they rise faster than the household income required to service mortgages and other housing costs. As indicated by Figure 4, homes are valued fairly in the United States, but in Australia and Canada, housing looks severely expensive.

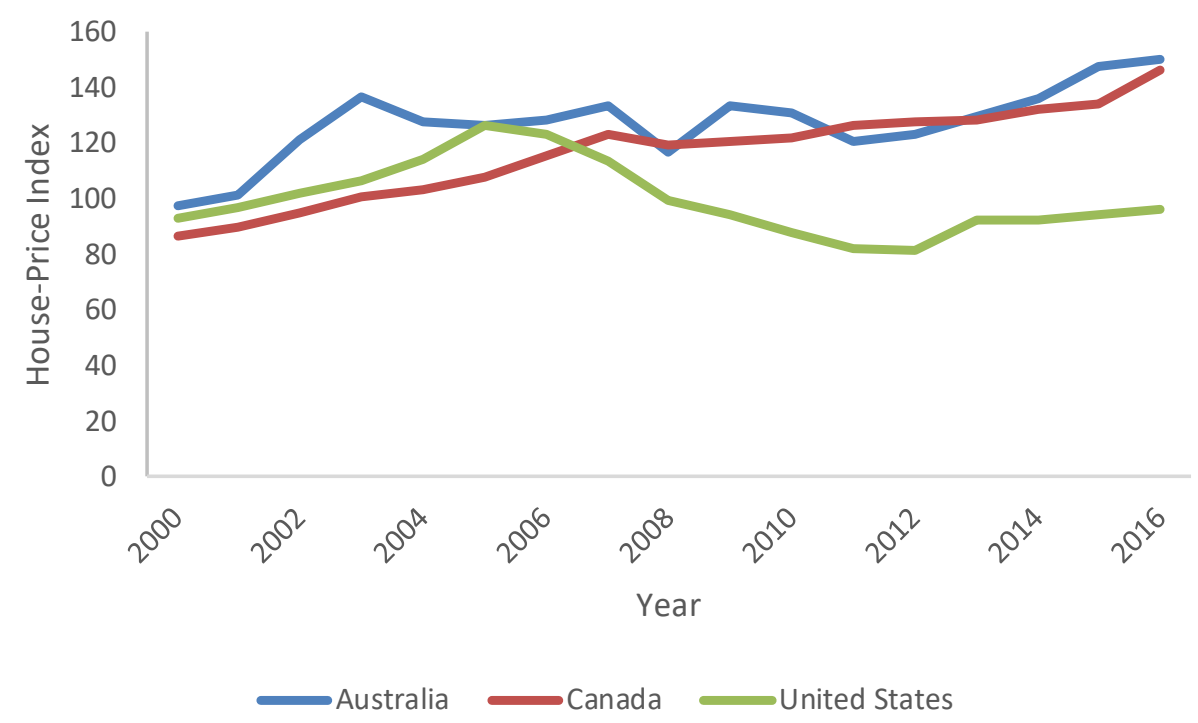

Figure 4. House price index relative to average income for Australia, Canada, and the United States, 2000 to 2016.

Source: Economist 2017.

Note: Housing price index is relative to 1980-2016 long-term average for each country: longterm average $=100$.

Housing prices are relatively high in Toronto and Vancouver for many Canadians, and particularly for recent immigrants. Today, most immigrants in Canada's largest metropolitan areas-with the possible exception of Montreal_ seek housing in suburban areas, where homes are more affordable. But ongoing expansion of metropolitan areas presents challenges for urban planning, including rising demands for land and housing in more distant areas, and the need for more efficient metropolitan transportation services.

In other countries, local authorities have developed two main types of housing policies for immigrants (see Balbo 2005 for a discussion of immigrant housing policies in several countries, including Brazil, Canada, Germany, Italy, Mexico, and Thailand). One is directed at creating housing that is accessible to newly arrived immigrants. These policies have been used primarily in countries with large poor immigrant populations and are not generally applicable to higher-income countries. The second policy is to provide urban housing services throughout the city, to facilitate linkages between newcomers and available housing. 


\section{Social services}

Knowing about and accessing social services is another important issue for immigrants. Although responsibility for social services has increasingly devolved to metropolitan governments, many have not taken a proactive role in delivering immigrant services, but rather rely on existing social service agencies to handle immigrant issues. Immigrants, in turn, have tended to rely on nongovernment services and the private sector, or be self-reliant to a large extent. Non-government services, however, are typically not integrated or widely accessible for newly arriving immigrants. A few governments, such as the state of Massachusetts in the United States, have established programs that offer a direct contact for immigrants, with links to non-government services. ${ }^{4}$

\section{Employment}

Finding employment poses several interrelated problems. It is difficult for some immigrants to find suitable full-time employment, and immigrants are often either unemployed or have to accept part-time employment in their first years after arrival. Other immigrants may find employment that does not match their skills and interest. This can happen because their credentials or experience are not recognized in Canada or there is little demand for their specific occupation.

At the same time that immigrants experience difficulties finding suitable employment, employers report there is unfilled employment in skilled occupations and trades, as well as unfilled employment in non-traditional settlement areas that are remote, rural, or have historically not received immigrants. Canada has pioneered selected immigration to non-traditional areas through its provincial nominee program. Much could be learned from this program to improve our understanding of the matching of immigrant and employment needs. Employment issues therefore include both underemployment of immigrants on the one hand, and a mismatch of immigrant human capital with labour market demands and the location of immigrants and jobs, on the other hand.

\section{Integration and cohesion}

The social integration of immigrants into Canadian society and maintaining social cohesion to include ever more diverse groups presents special challenges. Immigrants make cities more cosmopolitan and bring rich rewards to the arts, culture, sports, and cuisine. But immigration can also bring anxiety and concern to some longer-established residents.

Social inclusion has been sufficiently recognized as an important and integral part of a successful immigrant policy. Metropolitan officials usually acknowledge it in order to foster economic growth and support improvements in social services. But if a metropolitan area is to be a polisthat is, a place where different people come together-then policies must ensure the inclusion of new residents and tackle the barriers to social inclusion.

Social inclusion has several aspects, including (a) access to security in housing, health, educational, and social services; (b) access to public decision-making; and (c) development of new collective identities that counter the entrenchment of mutual suspicions and distrust. A cornerstone of social inclusion strategies must be the participation of migrants or their representatives in metropolitan public forums and city councils. Just as fundamental to social inclusion is public information on the origins and causes of migration, and on the costs and benefits to local communities of receiving international migrants. It is worrisome, for example, that many Canadians incorrectly believe that the public benefits immigrants receive exceed their public payments. In fact, in Canada and other countries, such as the United States, the average immigrant contributes

4. Information about the Massachusetts Office of Refugees and Immigrants is available at http://www.mass. gov/eohhs/gov/departments/ori/. 
more in public payments (mainly through taxes) over their lifetime than they receive in public benefits (primarily health care and retirement income). Setting the record straight would increase public support for efforts to promote the social inclusion of immigrants.

\section{Expanding our knowledge base}

This brief paper is the first step in a discussion of important implications for broadening our knowledge base. Further attention is needed on several critical questions concerning Canada's migration challenges.

First, finding adequate housing and social services is one of the most important problems for newly arrived immigrants, yet there is relatively little study of this topic. Second, considerable research exists on employment and social inclusion problems for immigrants, although the literature is diverse and often not easily accessible to policymakers. Concise reports with policy recommendations would help to summarize and interpret this literature to facilitate appropriate policymaking.

We conclude with a discussion of data needs for improving immigration research. Most immigration research uses current survey and census data collected by Statistics Canada. There are two broad areas for possible improvement. First, immigration research benefits greatly from surveys that include four essential questions: (1) place of birth of the respondent; (2) date of arrival in Canada; (3) citizenship status; and (4) parental nativity (place of birth of respondent's parents). Parental nativity data provide the information required to examine the social and economic characteristics of the sons and daughters of immigrants. Children of immigrants are a critical generation for study, because they reflect the relative success and rapidity of adjustment of immigrants to Canadian society. Children of immigrants are a pivotal subgroup of a national population increasingly affected by large scale immigration. The value of survey data for immigration research would be greatly improved if they include these four essential immigration related questions.

Second, some otherwise useful Canadian surveys lack adequate sample sizes for the analysis of immigrants. Small sample sizes reduce the reliability of findings, particularly when comparing across sub groups of immigrants. It would be very useful to incorporate over sampling of immigrants in designing surveys, to enhance the value of these surveys for studying immigrants.

Third, in addition to Canada's general population and survey data, several specific data sources are especially useful for immigration study. Canada's Longitudinal Survey of Immigrants to Canada provides valuable information on the first four years of residence in Canada for 4,422 immigrants who arrived between October 2000 and September 2001; however, attrition rates of the immigrants in the sample were high. In addition, longitudinal data on immigrants require repeated samples of immigrant cohorts, because the composition of immigrant cohorts changes over time, as do the social and economic conditions they experience after arrival. At present, however, the high cost of new longitudinal immigrant surveys outweighs their research value compared to other possible data.

Several other sources of immigration data are useful. Canada's Longitudinal Immigration Database (IMDB) offers data on linked administrative immigration and tax files for immigrants arriving since 1980 and their tax returns (if they filled at least one return since 1982). IMDB currently includes more than 30 years of data for 6 million immigrant records, available for studies related to employment, income, and geographic mobility of immigrants.

The French Permanent Demographic Sample (EDF) is an interesting approach for longitudinal data that could be used in other countries. EDF corresponds to a 1-per-cent sample of the French population over time. The longitudinal data set was created in 1967 by l'Institut national de la statistique et des études économiques (INSEE), based on a sample of all French residents. INSEE subsequently linked the large sample of individuals to census files from 1968 and later, adding newly 
arrived immigrants in each census. The EDF has data from each census, but because they are linked over time, it offers information on changes in education, employment, income, family relationships, and other census variables. Also, because the EDF includes a large sample of French-born, foreignborn, and children of the foreign-born, it allows comparisons between these groups.

Finally, as in past censuses, Statistics Canada links census data with other administrative data in order to assess coverage and accuracy. For the 2016 census, data were linked to Immigration, Refugees, and Citizenship Canada's (IRCC) immigrant arrival data. These linked data provide improved information on date of immigrant arrival, immigrant admission category (which is not asked in the census), and other information that is available in the IRCC's administrative data. Future analysis of these linked data might study the relationship between the conditions under which immigrants were admitted and socio-economic outcomes measured in the census.

\section{References}

Balbo, M. (ed). 2005. International Migrants and the City. Nairobi: UN Human Settlement Programme.

Blau, F.D., and C. Mackie (eds). 2017. The Economic and Fiscal Consequences of Immigration. A Report of the Panel on the Economic and Fiscal Consequences of Immigration. Washington: National Academy Press.

The Economist. 2017. Housing-Price Index-Infographics, https://infographics.economist.com/2017/ HPI/index.html, downloaded 28 November 2017.

Edmonston, B. 2016. Canada's immigration trends and patterns. Canadian Studies in Population 43(12):1-39. Special Issue on Canada and Australia: Social Demographic Trends and Patterns, coedited by R. Beaujot and P. McDonald.

Florida, R., C. Mellander, and T. Gulden. 2009. Global Metropolis: The Role of Cities and Metropolitan Areas in the Global Economy. Martin Prosperity Research Working Paper Series. Toronto: Martin Prosperity Institute, University of Toronto.

International Organization for Migration. 2017. World Migration Report 2018. Geneva: International Organization for Migration.

OECD. 2013. International Migration Outlook, 2013. Paris: Organisation for Economic Co-operation and Development.

- 2017. International Migration Outlook, 2017. Paris: Organisation for Economic Co-operation and Development.

Population Reference Bureau. 2007. World Population Data Sheet, 2007. Washington: Population Reference Bureau.

—. 2015. World Population Data Sheet, 2015. Washington: Population Reference Bureau.

Statistics Canada. 2007. Longitudinal Survey of Immigrants to Canada, Wave 3: User's Guide. Ottawa: Special Surveys Division, Statistics Canada.

- 2010. Projections of the Diversity of the Canadian Population, 2006 to 2031. Catalogue no. 91-551X. Ottawa: Minister of Industry.

- 2017. Immigrants and ethnocultural diversity: Key results from the 2016 Census. The Daily, 25 October 2017.

United Nations. 2016. International Migration Report 2015: A Global Assessment. New York: United Nations Population Division. 